\title{
Suitability of water treatment chemicals in the remediation of produced water: a data-driven approach
}

\author{
Clifford Okwudili Aniakor ${ }^{1}$ iD
}

Received: 26 May 2021 / Accepted: 11 September 2021 / Published online: 24 September 2021

(c) The Author(s) 2021

\begin{abstract}
There exist numerous counts of research works on produced water. We got to know about them because they made it to publishing probably by indicating a positive or promising result. Contrarily, there exist a hundred times unpublished, unreported works on produced water; works rejected based on not yielding desirable results or not being innovative enough. We might have encountered undesirable results but to what depths and time have we committed to mining out intricate details. The world is thinking and demanding sustainability. Is it sustainable for the future of water treatment, the ease and pace at which we transition to the next chemical or treatment option? In this data-centred approach, three common chemicals, aluminium sulphate, ferrous ammonium sulphate and calcium chloride, were used to treat produced water. The collected data (both initial and final analysis) were inferentially analysed. The first statistical analysis was the testing of 2 hypotheses using the Analysis of Variance test. This was done to reveal to compare the dependence of produced water properties on two categorical variables (sample type and treatment chemicals). The second was the test for relevance: correlation and regression analyses. The laboratory experimental analysis revealed that aluminium sulphate was most suitable for the alteration of physical effluent characteristics; ferrous ammonium sulphate for salinity concerns and calcium chloride for a particular heavy metal's stability. The overall effluent characteristics indicated a greater dependency on 'sample type' than 'treatment chemicals'. Certain produced water properties relationships were highlighted and quantified for instance iron(II) and chloride ion concentrations were dependent on total solids and indicated a significance $F$ of 0.01 .
\end{abstract}

Keywords Produced water $\cdot$ Data-driven approach $\cdot$ Statistical hypothesis testing $\cdot$ Cost-effective treatment

\section{Introduction}

With the beginning of a new decade, one would expect new challenges, but some continuously exist. Presently, one of such for the oil and gas industry is produced water. An inevitable and toxic form of our most essential resource-water. Inevitable because one cannot exploit our underground resource (oil and gas) without it coming along eventually. Toxic? This water contains variable levels of pollutants such as dissolved solids, heavy metals, unstable anions, oils and grease, organic compounds. Currently, the world is waking up to the effects of climate change and how pollution is an undeniable hinder to sustainability. Produced water is wastewater generated alongside oil and gas (Clark and Veil 2009).

Clifford Okwudili Aniakor

cliffj19@gmail.com

1 Department of Petroleum Engineering, Rivers State University, Port Harcourt, Nigeria
Produced water is often referred to as brine or formation water. It represents the largest waste generated from the production process. Clark and Veil (2009) predicted produced water volumes to increase by $32 \%$ by 2025 .

\section{Why should we treat produced water 'better'?}

On the 3rd of March, 2021, at the United Nations Human Rights Council, UN HRC in Geneva, David Boyd, the United Nations' Special Rapporteur on human rights and environment stated "The world faces a water crisis and it is getting worse...3/4 of all the natural disasters in the last 20 years were water-related... water pollution, water scarcity, water-related disasters and damage to healthy freshwater ecosystems have major impacts on a wide range of human rights...". He recommended five steps for addressing the global water crisis - one of which includes a state-of-the-art water assessment (UN OHCR 2021). The toxicity and complexity of the constituents of produced water make it a factor 
in the mitigation of the global water crisis. Surface interactions between hydrocarbons and their enclosed geologic formations encourage chemical reactions which yield organic and inorganic products with high toxicity levels (Benko and Drewes 2008). Products such as radionuclides (a radioactive atom/element which has an unstable nucleus due to its excess nuclear energy) and oil droplets are very difficult to treat and they pose direct harm to both the environment and human life (Liangxiong et al. 2004). Also, environmental protection agencies have been established worldwide on different government tiers with strict rules and regulations to control and monitor the discharge of produced water due to its different complex chemical nature and large production volumes. Produced water contains heavy metals that biomagnify and other organic contaminants such as asphaltenes, naphthenic acids and resins (Pimentel et al. 2008; Li et al. 2006). Produced water could ruin earth's terrain, pollute water bodies thereby endangering our aquatic ecosystem, our land, crops, the often-forgotten microbial ecosystem and raise stable elements above trophic levels when not treated and disposed of properly. The conventional treatment method which involves subsequent discharge is the gravitybased separation (Fakhru'l-Razi et al. 2009). Furthermore, disposal as surface waters requires optimum treatment of all suspended and dissolved components. The dissolved components contribute to the chemical oxygen demand which reduced the dissolved oxygen levels creating an anaerobic aquatic ecosystem (Liangxiong et al. 2004). For instance, alkylphenols which do not require bioaccumulation due to their already high concentration (present in produced water and is also incorporated in detergents) causes feminization of fish in polluted rivers and upsets the reproductive makeup of rodents (Markey et al. 2001).

\section{Cost of treatment}

Colorado School of Mines/ Advanced Water Technology Center (n.d.) summarized the overall treatment cost into 5: construction cost treatment and disposal structures; operating cost of these structures; management cost of byproducts generated during treatment; transportation cost; permits, reports and monitoring costs. The website also reports that total cost ranges from less than 1 cent/bbl to more than $\$ 5 / \mathrm{bbl}$. For agricultural standards, (Burnett and Siddiqui 2006) report treatment costs to range from $\$ 0.5$ to $\$ 1.5 / \mathrm{bbl}$. For instance, thermal treatment technologies such as hybrid multi-effect distillation-vapour compression (MED-VCD) have a capital cost ranging from \$250-\$360 per bpd, operating cost and total unit costs of $\sim \$ 0.12 / \mathrm{bbl}$ and $\$ 0.19 / \mathrm{bbl}$, respectively (Igunnu and Chen 2014). Igwe et al. (2013) examined the factors and methods for handling wastes stating; "from practical experience, the feasibility of choosing a particular disposal system is usually dependent on cost contributing factors (such as transportation, treatment and development of disposal site) as well as environmental regulations. Some of the techniques being currently used are disposal to surface water; disposal to sewer; re-injection into the reservoir (through injection well); discharge to evaporation pond; spray evaporation and application of zero liquid discharge".

\section{The chemical treatment of produced water}

Various classes of chemicals are widely used in water treatment. Some of these include oxidants such as ozone; alkalinity control agents for example lime; coagulants such as aluminium sulphate and organic polymers; corrosion inhibitors for instance silicates and morpholine. They can either be used as standalone treatments or incorporated with other treatment technologies (usually in the pretreatment phase or as cleaning agents) such as ceramic MF/UF membrane, reverse osmosis, vapour compression distillation, macro-porous polymer extraction technology, gas floatation, media filtration.

These chemicals have been experimented with and utilized in produced water treatment. Hosny and Ramzi (2017) compared the treatment efficacy between two natural polymers (chitin and chitosan) on produced water for the reduction of formation damage. Despite using a simultaneous mixture of local materials in their treatment design, Udeagbara et al. (2020) had to initially wash the ground materials with $0.4 \mathrm{~mol} / \mathrm{L} \mathrm{HNO}_{3}$. Zakwan et al. (2018) designed a treatment solution using an advanced oxidation process from $\mathrm{H}_{2} \mathrm{O}_{2}$ and $\mathrm{UV}$ radiation to degrade toxic components in chemically enhanced oil recovery (CEOR) produced water. Carus Group Inc. (2019) stated permanganate oxidizes soluble iron, manganese, hydrogen sulphide and mercaptans in produced water. Inorganic coagulants such as aluminium sulphate and ferric chloride consist of some of the most widely used coagulants for the removal of suspended and colloidal particles. Rodriguez et al. (2020) stated a downside to their usage includes large masses of residual sludge and their discouraging compound to element ratio-1 ton of ferric chloride $\mathrm{FeCl}_{3} \cdot 6\left(\mathrm{H}_{2} 0\right)$ yields $210 \mathrm{~kg}$ of $\mathrm{Fe}(\mathrm{III})$.

When treating produced water, one of the recurring processes is chemical dosing. Manual chemical dosing isn't usually recommended for large-scale applications because it is error-prone. Mechanical chemical dosing is achieved using dosing pumps and meters such as peristaltic pumps and diaphragm pumps. Intelligent chemical dosing incorporates AI, machine learning and the Internet of Things (IoT) to achieve continuous automated dosing optimization. Examples of this dosing system include Emagin and OpWorks technologies. 


\section{A data-driven approach}

When an experimental treatment analysis is carried out on produced water, comparisons are made between final and initial results and oftentimes when undesired change is achieved, the results, chemicals used and treatment design are often discarded and the next treatment option is soughtafter. The end result isn't all there is to a mixture as complex as produced water.

Inferential statistics covers an array of decision-making tools that utilize inductive reasoning to yield a probability for validity instead of the traditional right or wrong. Statistical hypothesis testing (or confirmatory data analysis) is one of those tools. It is used to verify an experimental aim against a conventional belief - this is often referred to as statistical significance. It is utilized in the medical field to test drugs and procedures (Dubois n.d.). It is also widely utilized in philosophical science. Repeated testing is an alternative to statistical hypothesis testing but it isn't lean. Repeated testing requires several repeated experimental runs and an increase in sample size. (Nickerson 2000). Inferential statistics might be criticized as time-consuming but presently there are several software applications with user-friendly experiences and interfaces (UX and UI) capable of automating calculations within seconds such as R, Python, Microsoft Excel, Minitab and IBM SPSS.

Another sustainable application of produced water experimental data is for correlation and regression analysis. These two have continuously formed the basis for foundational theories in science and engineering for instance the relationship between density and volume, coagulant dosage and settling time. Hypothesis testing might validate this, but it cannot quantify and mathematically express these theories. Results derived from correlation and regression analysis are indispensable; and since produced water still presents a threat to global water pollution control, it is paramount that every data on its composition, properties, treatment be collected. We can't say when we might need it but we can still keep it.

\section{Aim and selection criteria}

The option of using easily sourced, relatively inexpensive methods has been overlooked due to the nagging existence of this toxic water. In this work, chemicals-'essential toxins', were used to treat, alter, limit alarming ones (contained in produced water). A widely used coagulant (aluminium sulphate), a double salt of two treatment salts (ferrous ammonium sulphate) and a generally used laboratory chemical (calcium chloride) were each utilized. According to C. N. Harmony (personal communication, July 1, 2019), the selection criteria included simplicity in treatment design and affordability of these chemicals to encourage treatment and manage waste. Before the actual designed treatment process, produced water often goes through a dosing phase which involves the addition of flocculants and scale inhibitors (Nwosi-Anele and Illedare 2016).

The aim is to extensively investigate the tri-fold suitability which includes dosing suitability, statistical suitability and output models suitability. These will combine to create an archetypical template that could be widely utilized for wastewater treatment considerations and options selection.

\section{Methodology}

Two (2) Produced water samples collected from the different reservoirs in the Niger Delta region of Nigeria were analysed. The parameters analysed include $\mathrm{pH}$, capillary viscosity, temperature, apparent colour, total dissolved solids, total suspended solids, total solids, turbidity, oils and grease, sulphate ion, chloride ion, nitrate ion, calcium carbonate, calcium ion, sodium ion, barium ion, iron(II) ion, magnesium ion concentrations. See Table 1 for method of analysis.

To determine the suitable concentration of treatment chemicals needed, $200 \mathrm{mg} / \mathrm{l}, 500 \mathrm{mg} / \mathrm{l}$, and $1000 \mathrm{mg} / \mathrm{l}$ of the 3 treatment chemicals concentration were dissolved in the produced water samples. The 18 treated samples were

\begin{tabular}{|c|c|c|}
\hline & Method of analysis \\
\hline \multicolumn{2}{|l|}{ pH and Temperature $\left({ }^{\circ} \mathrm{C}\right)$} & Electronic Method \\
\hline \multicolumn{2}{|l|}{ Apparent Colour } & Human Eye \\
\hline \multicolumn{2}{|l|}{$\begin{array}{l}\text { Total dissolved solids }(\mathrm{mg} / \mathrm{l}) \\
\text { Total suspended solids }(\mathrm{mg} / \mathrm{l}) \\
\text { Total solids(mg/l) }\end{array}$} & Gravimetric Analysis \\
\hline Turbidity (NTU) & & Nephelometer \\
\hline Oils and Grease (mg/l) & & Extraction, Acidification and Gravimetric Analysis \\
\hline $\mathrm{SO}_{4}^{2-}(\mathrm{mg} / \mathrm{l})$ & $\mathrm{Ba}^{2+}(\mathrm{mg} / \mathrm{l})$ & Acidification, $\mathrm{BaCl}$ Addition and Gravimetric Analysis \\
\hline $\mathrm{Cl}^{-}(\mathrm{mg} / \mathrm{l})$ & $\mathrm{Na}^{+}(\mathrm{mg} / \mathrm{l})$ & $\mathrm{AgNO}_{3}$ Titration \\
\hline $\mathrm{CaCO}_{3}(\mathrm{mg} / \mathrm{l})$ & $\mathrm{Ca}^{2+}(\mathrm{mg} / \mathrm{l})$ & EDTA Titration \\
\hline $\begin{array}{l}\mathrm{NO}^{-}(\mathrm{mg} / \mathrm{l}) \\
\mathrm{Fe}^{2+}(\mathrm{mg} / \mathrm{l})\end{array}$ & $\mathrm{Mg}^{2+}(\mathrm{mg} / \mathrm{l})$ & Atomic Absorption Spectroscopy, AAS \\
\hline
\end{tabular}


stirred. The flocs and other suspended matter were decanted. The capillary viscosity and $\mathrm{pH}$ of each trial sample were measured and compared. The dosage of $200 \mathrm{mg} / \mathrm{l}$ was chosen since it did not alter the initial capillary viscosities of the produced water samples and posed the least significant change in $\mathrm{pH}$.

$200 \mathrm{mg} / \mathrm{l}$ concentrations of each treatment chemicals in the produced water samples were created. The samples were rapidly agitated for $60 \mathrm{~s}$ for the production of a micro-floc. The 6 samples ( 2 by 3 ) were agitated slowly for $25 \mathrm{~min}$ to form a floc capable of settling. The samples were then left to settle for $3 \mathrm{~h}$. A sieve (with mesh size capable of not altering total solids values) was used to clear off flocs.

Final physiochemical laboratory analyses of the 6 samples ( 2 by 3 ) were carried out.

Statistical analyses were carried out on the experimental results. The first was using a suitable hypothesis testing tool (Analysis of Variance). The second, correlation and regression analyses were done in other to reveal useful insights.

The treatment chemicals utilized are inorganic coagulants which are known for forming metallic precipitates capable of absorbing impurities in water (Jones 2020). Dissolving aluminium sulphate in water causes a fraction of the aluminium to dissociate into the highly charged $\mathrm{Al}^{3+}, \mathrm{Al}(\mathrm{OH})^{2+}$, $\mathrm{Al}(\mathrm{OH})_{2}{ }^{+}$which neutralize the negatively charged impurities suppressing their zeta potential. However, calcium chloride and ferrous ammonium sulphate produce divalent cations $\left(\mathrm{Ca}^{2+}\right.$ and $\left.\mathrm{Fe}^{2+}\right)$ resulting in a lower neutralization potential on impurities (Bennett 2006).

The dissociation of the treatments chemicals is expressed below:

$$
\begin{aligned}
& \mathrm{Al}_{2}\left(\mathrm{SO}_{4}\right)_{3(\mathrm{~s})}+\mathrm{H}_{2} \mathrm{O}_{(l)} \rightarrow 2 \mathrm{Al}_{(a q)}^{3+}+3 \mathrm{SO}_{4(a q)}^{2-} \\
& \mathrm{FeSO}_{4} \cdot\left(\mathrm{NH}_{4}\right)_{2} \mathrm{SO}_{4} \cdot 6 \mathrm{H}_{2} \mathrm{O} \\
& \quad \rightarrow^{\text {Excess } \mathrm{H}_{2} \mathrm{O}} \mathrm{Fe}_{(a q)}^{2+}+2\left(\mathrm{NH}_{4}\right)_{(a q)}^{+}+2 \mathrm{SO}_{4(a q)}^{2+}+6 \mathrm{H}_{2} \mathrm{O} \\
& \mathrm{CaCl}_{2}+\mathrm{H}_{2} \mathrm{O} \rightarrow \mathrm{Ca}_{(a q)}^{2+}+2 \mathrm{Cl}_{(a q)}^{-}
\end{aligned}
$$

For bicarbonate, carbonate and hydroxide impurities, a significant concentration of these treatment chemicals is needed to precipitate $\mathrm{Al}(\mathrm{OH})_{3}, \mathrm{Fe}(\mathrm{OH})_{2}$ and $\mathrm{Ca}(\mathrm{OH})_{2}$ (Bhanderi and Ranade 2014). An example of the reaction is shown below:

$$
\begin{aligned}
& \mathrm{Al}_{2}\left(\mathrm{SO}_{4}\right)_{3} \cdot 14 \mathrm{H}_{2} \mathrm{O}+6 \mathrm{HCO}_{3}^{-} \\
& \quad \leftrightarrow 2 \mathrm{Al}(\mathrm{OH})_{3} \downarrow+6 \mathrm{CO}_{2}+14 \mathrm{H}_{2} \mathrm{O}+3 \mathrm{SO}_{4}^{2-}
\end{aligned}
$$

According to Bhanderi and Ranade (2014), the precipitating ability of the treatment chemicals to produce $\mathrm{Al}(\mathrm{OH})_{3}$, $\mathrm{Fe}(\mathrm{OH})_{2}$, and $\mathrm{Ca}(\mathrm{OH})_{2}$ is a function of the produced water's $\mathrm{pH}$. Conventionally, most inorganic coagulants require quick mixing mechanisms for effective distribution of the intermediate products stated above because these products are the destabilizing agents and they are short-lived.

\section{Observation}

Table 2 contains the physical observations recorded when the treatments chemicals were added to the produced water samples.

\section{Results}

Table 3 contains the results of the analyses of the two produced water samples both before and after treatment with respect to the three treatment chemicals. The last two columns contain Nigeria's Department of Petroleum Resources (DPR) limits for both inland and nearshore disposal.

Table 4 contains two split heat maps illustrating the percentage changes before and after treatment for the 2 produced water samples. Each map was delimited to add up the cumulative change in physical and chemical properties. For samples "A" and "B", aluminium sulphate yielded the most positive change in physical properties, while the sam-

\begin{tabular}{|c|c|c|}
\hline Treatment chemicals & Immediate observations & Observations after settling time \\
\hline Aluminium Sulphate & $\begin{array}{l}\text { Lighter Contrast. The appearance of suspended matter. } \\
\text { No apparent heat loss or gain }\end{array}$ & $\begin{array}{l}\text { Settled bottom suspended matter. Collection of lesser } \\
\text { matter on the top layer. The increased mass of sus- } \\
\text { pended matter }\end{array}$ \\
\hline Ferrous Ammonium Sulphate & $\begin{array}{l}\text { Deeper Contrast. The appearance of suspended matter. } \\
\text { No apparent heat loss or gain }\end{array}$ & $\begin{array}{l}\text { Settled bottom suspended matter. The increased mass of } \\
\text { suspended matter }\end{array}$ \\
\hline Calcium Chloride & $\begin{array}{l}\text { No noticeable colour changes. Collection of oil films } \\
\text { on beaker's walls. No apparent heat loss or gain }\end{array}$ & The increased mass of oil films \\
\hline
\end{tabular}
ples treated with calcium chloride yielded the least negative change in chemical properties.

Since three treatment chemicals were used, we can graphically depict their normalized concentrations (to sum 100)

Table 2 Observations upon addition of chemicals to samples before and after settling hours 
Table 3 Initial and final analysis with DPR limits

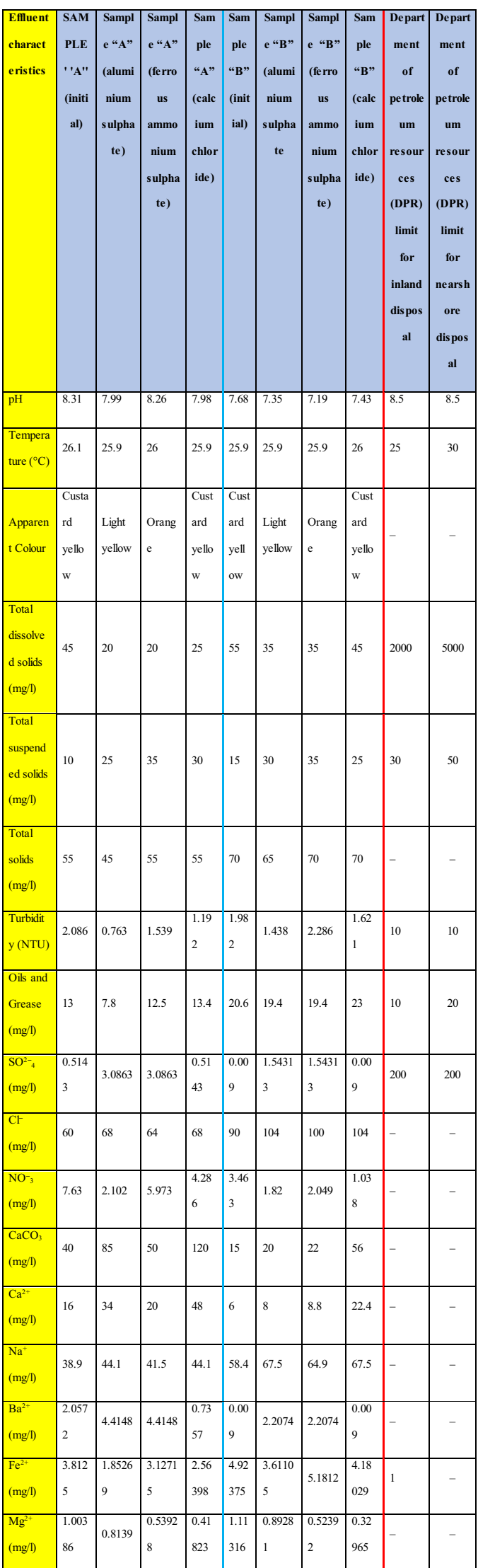

in equilateral triangles as shown in Figs. 1, 2, 3 and 4 above. The ternary diagrams were designed separately for the physical and chemical properties to avoid clustering of points due to the number of parameters analysed. Figures 1 and 3 illustrate the quantifiable physical properties while Figs. 2 and 4 are for the chemical properties. The figures might also reveal a hypothesized tri-fold compositional effect should the-one-chemical-per-sample design be replaced by threechemicals-cocktail-per-sample given that ternary plots are widely incorporated in phase diagrams. Addinsoft (2021) was used in designing the ternary graphs.

Table 5 contains the frequency distribution, measures of variability and the central tendency for all quantitative variables in Table 3. Skewness and Kurtosis reveal the disparity between an observed distribution and the ideal normal distribution. $\mathrm{SO}^{2-}{ }_{4}$ concentrations for both samples yielded skewness values of 0 which is typical of a normal distribution. Also, $\mathrm{SO}^{2-}{ }_{4}$ concentrations for both samples were bimodal. Sample B's $\mathrm{Ba}^{2+}$ values are also bimodal. For both samples, $\mathrm{CaCO}_{3}$ had the maximum ranges. $\mathrm{CaCO}_{3}$ also had the largest difference between mean and median values. A zero variance indicates a high similarity within recorded observations. This is so for Sample B's temperature values and to an extent that of sample A.

\section{Discussion}

Table 6 explains each property's experimental result.

\section{Comparison of the dependence of produced water properties on sample type and treatment chemicals}

Table 3 can be classically summarized as one containing 2 categorical independent groups namely sample types with 2 levels (A and B) and treatment options with 4 levels (initial, aluminium sulphate, ferrous ammonium sulphate and calcium chloride) and one dependent continuous variable (each numerical effluent characteristics). Due to the relatively large number of dependent variables compared to observations, the Multivariate Analysis of Variance (MANOVA) would not be suitable. The Two-Way Analysis of Variance (ANOVA) without replication is, therefore, the suitable hypothesis-testing method for the following hypotheses:

H01 For a particular water property, the final analysis results were not significantly influenced by the sample types.

Ha1 For a particular water property, the final analysis results were significantly influenced by the sample types. 
Table 4 Percentage change between initial and final analysis

\begin{tabular}{|c|c|c|c|c|c|c|}
\hline $\begin{array}{l}\text { Effluent } \\
\text { characteristics }\end{array}$ & \begin{tabular}{|l} 
Sample "A" \\
(aluminium \\
sulphate)
\end{tabular} & $\begin{array}{l}\text { Sample "A" } \\
\text { (Ferrous } \\
\text { Ammonium } \\
\text { Sulphate) }\end{array}$ & \begin{tabular}{|l|} 
Sample \\
“A” \\
(calcium \\
chloride)
\end{tabular} & $\begin{array}{l}\text { Sample "B" } \\
\text { (aluminium } \\
\text { sulphate }\end{array}$ & $\begin{array}{l}\text { Sample "B" } \\
\text { (ferrous } \\
\text { ammonium } \\
\text { sulphate) }\end{array}$ & \begin{tabular}{|l} 
Sample \\
"B” \\
(calcium \\
chloride)
\end{tabular} \\
\hline $\mathrm{pH}$ & $3.85 \%$ & $0.60 \%$ & $3.97 \%$ & $4.30 \%$ & $6.38 \%$ & $3.26 \%$ \\
\hline $\begin{array}{l}\text { Total dissolved } \\
\text { solids (mg/l) }\end{array}$ & $55.56 \%$ & $55.56 \%$ & $44.44 \%$ & $36.36 \%$ & $36.36 \%$ & $18.18 \%$ \\
\hline $\begin{array}{l}\text { Total } \\
\text { suspended } \\
\text { solids (mg/l) }\end{array}$ & $-150.00 \%$ & $-250.00 \%$ & $-200.00 \%$ & $-100.00 \%$ & $-133.33 \%$ & $-66.67 \%$ \\
\hline $\begin{array}{l}\text { Total solids } \\
(\mathrm{mg} / \mathrm{l})\end{array}$ & $18.18 \%$ & $0.00 \%$ & $0.00 \%$ & $7.14 \%$ & $0.00 \%$ & $0.00 \%$ \\
\hline $\begin{array}{l}\text { Turbidity } \\
\text { (NTU) }\end{array}$ & $63.42 \%$ & $26.22 \%$ & $42.86 \%$ & $27.45 \%$ & $-15.34 \%$ & $18.21 \%$ \\
\hline $\begin{array}{l}\text { Oils and } \\
\text { Grease (mg/l) }\end{array}$ & $40.00 \%$ & $3.85 \%$ & $-3.08 \%$ & $5.83 \%$ & $5.83 \%$ & $-11.65 \%$ \\
\hline $\begin{array}{l}\text { Cumulative } \\
\text { change in } \\
\text { physical } \\
\text { properties }\end{array}$ & $31.01 \%$ & $-163.77 \%$ & $-111.80 \%$ & $-18.92 \%$ & $-100.10 \%$ & $-38.67 \%$ \\
\hline $\mathrm{SO}^{2-}(\mathrm{mg} / \mathrm{l})$ & $-500.10 \%$ & $-500.10 \%$ & $0.00 \%$ & $-1701.11 \%$ & $-1701.11 \%$ & $0.00 \%$ \\
\hline $\mathrm{Cl}^{-}(\mathrm{mg} / \mathrm{l})$ & $-13.33 \%$ & $-6.67 \%$ & $-13.33 \%$ & $-15.56 \%$ & $-11.11 \%$ & $-15.56 \%$ \\
\hline $\mathrm{NO}_{3}^{-}(\mathrm{mg} / \mathrm{l})$ & $72.45 \%$ & $21.72 \%$ & $43.83 \%$ & $47.44 \%$ & $40.83 \%$ & $70.03 \%$ \\
\hline $\mathrm{CaCO}_{3}(\mathrm{mg} / \mathrm{l})$ & $-112.50 \%$ & $-25.00 \%$ & $-200.00 \%$ & $-33.33 \%$ & $-46.67 \%$ & $-273.33 \%$ \\
\hline $\mathrm{Ca}^{2+}(\mathrm{mg} / \mathrm{l})$ & $-112.50 \%$ & $-25.00 \%$ & $-200.00 \%$ & $-33 \%$ & $-47 \%$ & $-273 \%$ \\
\hline $\mathrm{Na}^{+}(\mathrm{mg} / \mathrm{l})$ & $-13.37 \%$ & $-6.68 \%$ & $-13.37 \%$ & $-15.58 \%$ & $-11.13 \%$ & $-15.58 \%$ \\
\hline $\mathrm{Ba}^{2+}(\mathrm{mg} / \mathrm{l})$ & $-114.60 \%$ & $-114.60 \%$ & $64.24 \%$ & $-24426.67 \%$ & $-24426.67 \%$ & $0.00 \%$ \\
\hline $\mathrm{Fe}^{2+}(\mathrm{mg} / \mathrm{l})$ & $51.40 \%$ & $17.98 \%$ & $32.75 \%$ & $26.66 \%$ & $-5.23 \%$ & $15.10 \%$ \\
\hline $\mathrm{Mg}^{2+}(\mathrm{mg} / \mathrm{l})$ & $18.92 \%$ & $46.28 \%$ & $58.34 \%$ & $19.79 \%$ & $52.93 \%$ & $70.39 \%$ \\
\hline $\begin{array}{l}\text { Cumulative } \\
\text { change in } \\
\text { chemical } \\
\text { properties }\end{array}$ & $-723.62 \%$ & $-592.08 \%$ & $-227.55 \%$ & $-26131.68 \%$ & $-26154.82 \%$ & $-422.29 \%$ \\
\hline
\end{tabular}




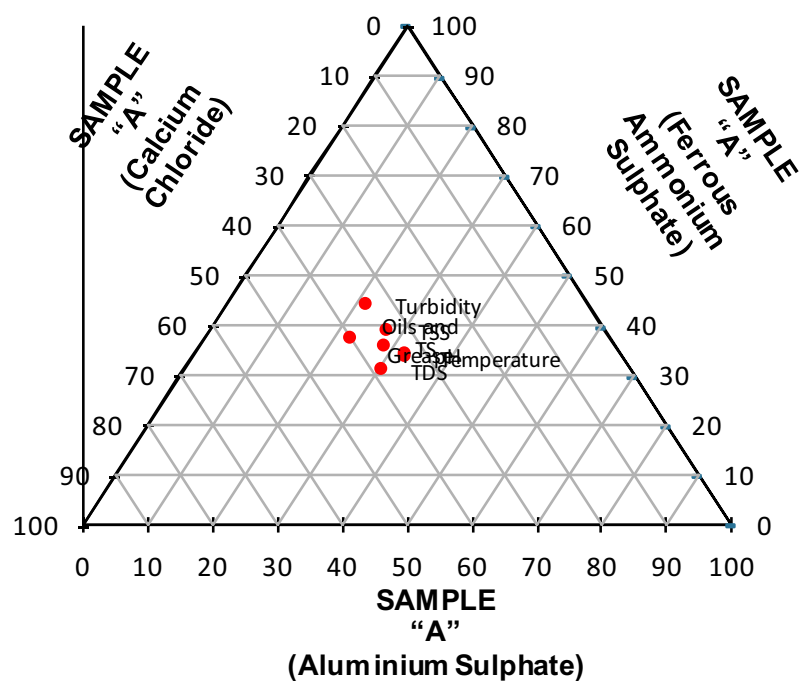

Fig. 1 Ternary diagram of sample A's continuous final physical properties

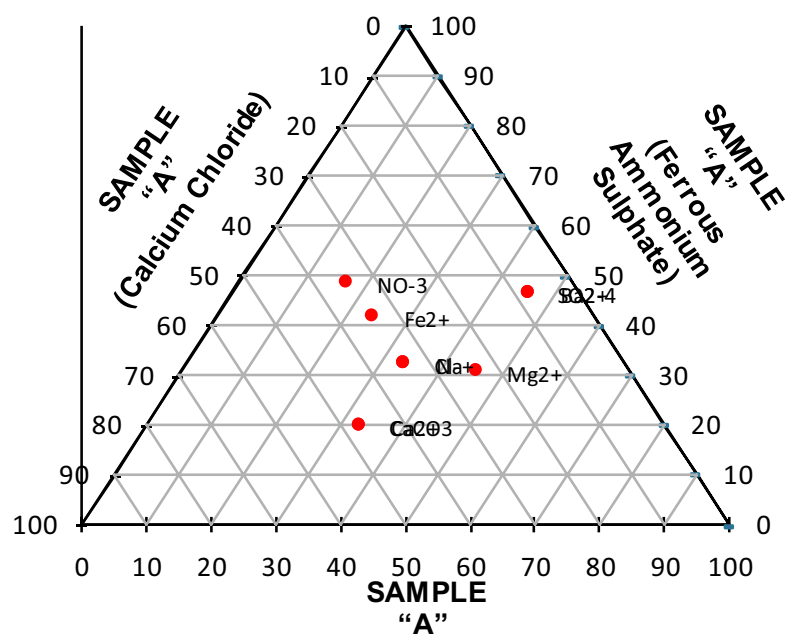

(Alum inium Sulphate)

Fig. 2 Ternary diagram for sample A's continuous final chemical properties

H02 For a particular water property, the final analysis results were not significantly influenced by the treatment chemicals.

Ha2 For a particular water property, the final analysis results were significantly influenced by the treatment chemicals.

The significance level $\alpha=0.05$. The block/row headers were the treatment options/chemicals while the column headers were the sample types for Table 7. Statistical Significance is achieved when P-value is less than alpha and the critical $F$-ratio is less than $F$-ratio. For total dissolved solids, total solids, $\mathrm{pH}$, oils and grease, $\mathrm{SO}^{2-}{ }_{4}, \mathrm{Cl}^{-}, \mathrm{NO}_{3}^{-}$, $\mathrm{CaCO}_{3}, \mathrm{Ca}^{2+}, \mathrm{Na}^{+}, \mathrm{Ba}^{2+}$ and $\mathrm{Fe}^{2+}$, the $1^{\text {st }}$ null hypothesis

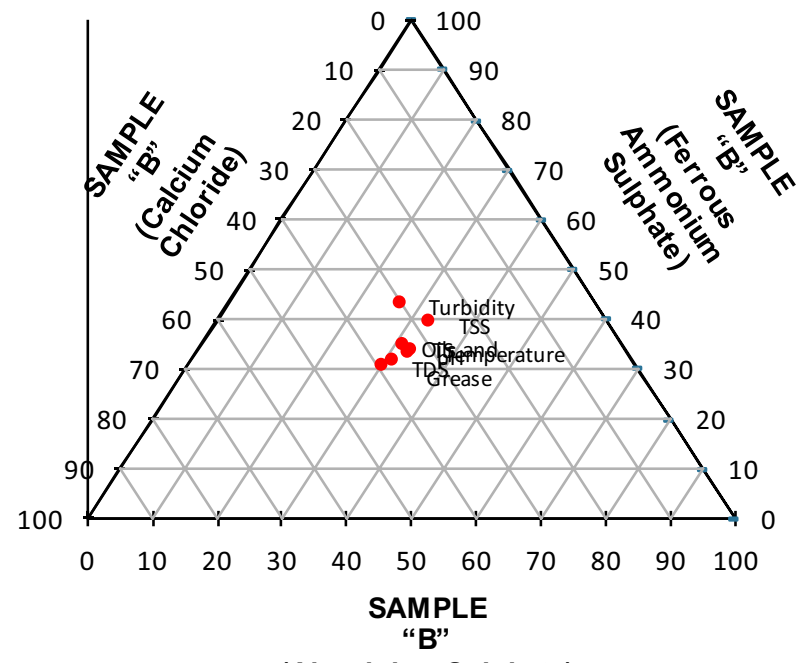

(Alum inium Sulphate)

Fig. 3 Ternary diagram for sample B'S continuous final physical properties

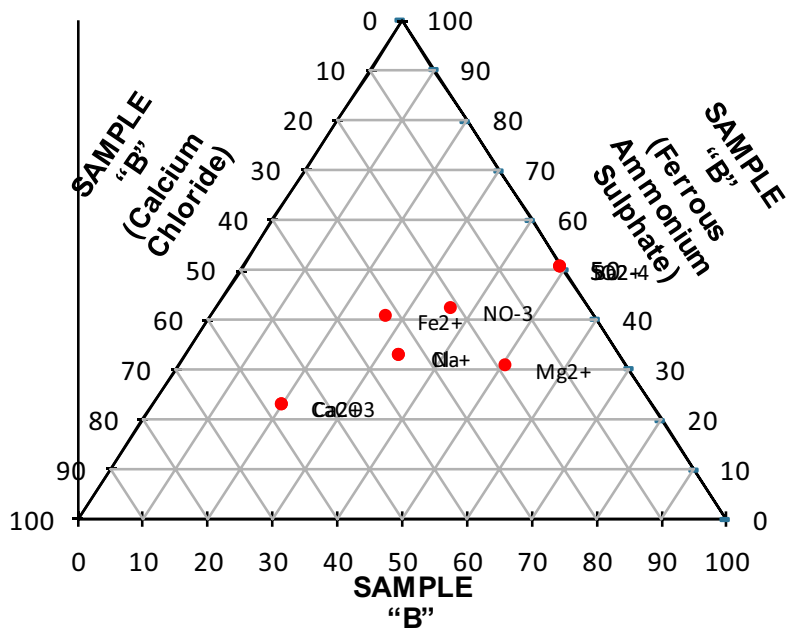

(Aluminium Sulphate)

Fig. 4 Ternary diagram for sample B's continuous chemical properties

was rejected (these properties were significantly influenced by the sample types) while for temperature, total suspended solids, turbidity and $\mathrm{Mg}^{2+}$, the 1 st null hypothesis was accepted (these properties were not significantly influenced by the sample types). For total suspended solids, total dissolved solids, total solids, $\mathrm{SO}^{2-}{ }_{4}, \mathrm{Cl}^{-}, \mathrm{Na}^{+}, \mathrm{Ba}^{2+}, \mathrm{Fe}^{2+}$, $\mathrm{Mg}^{2+}$ the 2 nd null hypothesis was rejected (these properties were significantly influenced by the treatment chemicals). On the other hand, $\mathrm{pH}$, temperature, turbidity, oils and grease, $\mathrm{NO}_{3}^{-}, \mathrm{CaCO}_{3}$ and $\mathrm{Ca}^{2+}$ accepted the 2 nd null hypothesis (these properties were not significantly influenced by the treatment chemicals). Total solids was on the 


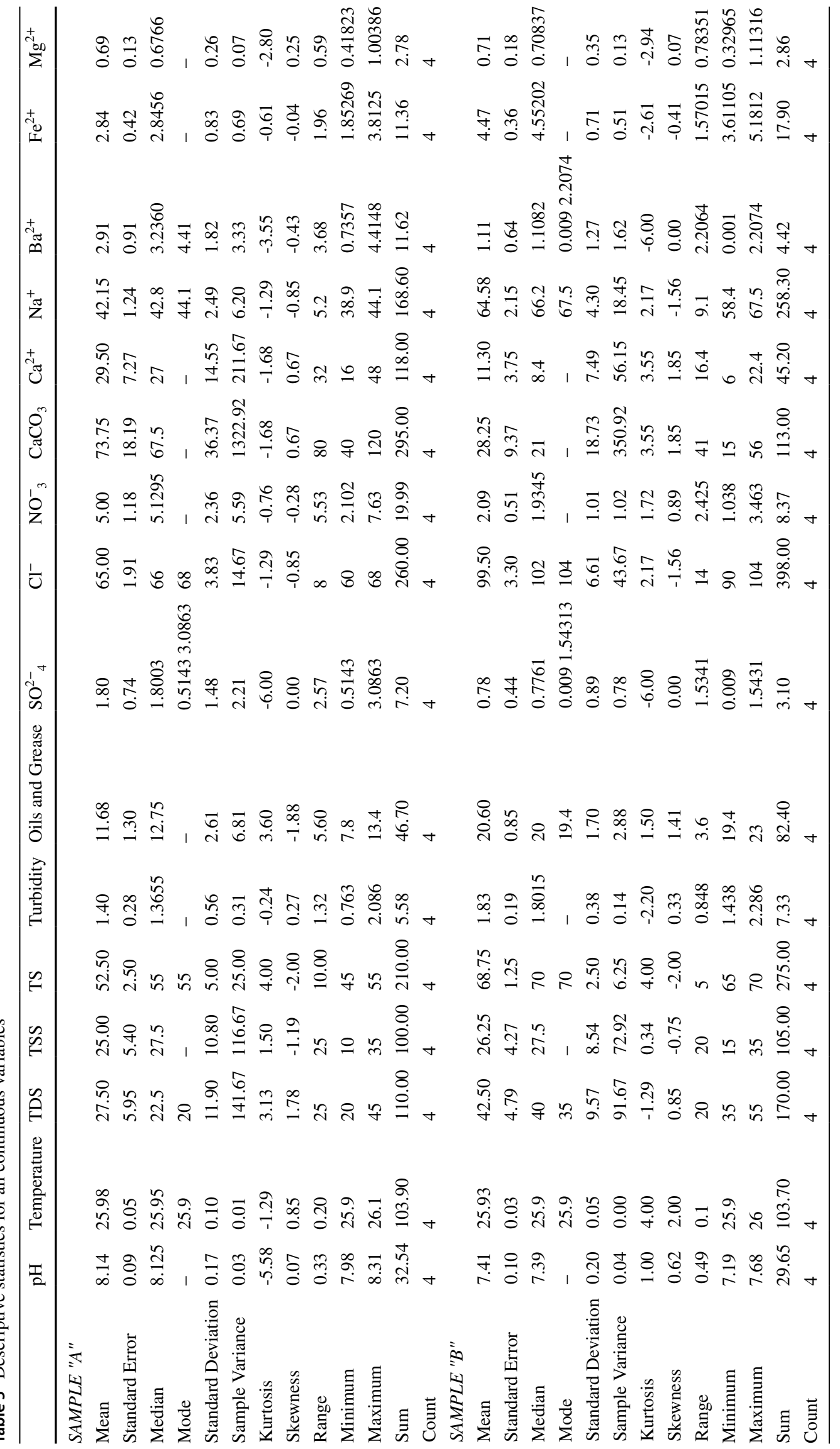


Table 6 Discussion of analysis data

\begin{tabular}{|c|c|}
\hline $\mathrm{pH}$ & $\begin{array}{l}\text { Since the chemicals used were salts, the slight shifts in } \mathrm{pH} \text { reveal the nature of these salts. According to Brandt et al. } \\
\text { (2017), when Aluminium sulphate is dosed in water, alkalinity is usually reduced due to the acidic nature of the } \\
\text { coagulant. A solution of ferrous ammonium sulphate in water turns blue litmus red hence, the reduction in both } \\
\text { samples A and } \mathrm{B} \text {. CaCl is a salt of a strong acid and strong acid thus forming a neutral solution in water }\end{array}$ \\
\hline TEMPERATURE & None of the chemicals initiated a thermal reaction. Hence, there is no significant change in temperature \\
\hline TDS and TSS & $\begin{array}{l}\text { The flocculation phase yields a decrease in TDS. The use of a sieve with a fairly large mesh size and the possibil- } \\
\text { ity of the flocculation process been ongoing even after } 3 \mathrm{~h} \text { could explain the irregularities in TSS. The formation } \\
\text { of chemical precipitates during treatment also supports this argument since chemical precipitates are considered a } \\
\text { form of suspended solids (Fondriest Environmental Inc. 2014) }\end{array}$ \\
\hline TURBIDITY & $\begin{array}{l}\text { Coagulants have long been demonstrated to encourage aggregation and settling of suspended particles by increas- } \\
\text { ing salinity for instance the visibly clear oceanic salt waters. the discouraging result from the ferrous ammonium } \\
\text { sulphate perfectly corresponds to its high TSS values }\end{array}$ \\
\hline OILS and GREASE & $\begin{array}{l}\text { It's worthy to note the reduction for this parameter in the aluminium sulphate-treated water. The calcium chloride } \\
\text { treated water increase suggests an ongoing deoiling process since oil films were initially observed in Table } 2\end{array}$ \\
\hline SULPHATE ION & $\begin{array}{l}\text { Aluminium sulphate and ferrous ammonium sulphate both partly dissociate into sulphate ions when dissolved in the } \\
\text { water. This combined with those recorded in the initial analysis led to an increase in its ionic concentration }\end{array}$ \\
\hline CHLORIDE ION & Here all treatment chemicals increased the chloride concentration and this raises serious concerns \\
\hline NITRATE ION & All 3 treatment chemicals yielded reductions in all samples \\
\hline $\begin{array}{l}\text { CALCIUM CARBON- } \\
\text { ATE AND CALCIUM } \\
\text { ION }\end{array}$ & The calcium chloride treated water produced the highest increase, hence the least suitable here \\
\hline SODIUM ION & Since high salinity prevents nitrogen intake in soils, ferrous ammonium sulphate had the safest result here \\
\hline IRON(II) ION & $\begin{array}{l}\text { Aluminium sulphate is the best option. Calcium is more reactive than iron. Hence, it is capable of displacing it in any } \\
\text { reaction }\end{array}$ \\
\hline BARIUM ION & $\begin{array}{l}\text { High barium levels trigger a high concentration of chloride, manganese, iron, strontium etc. Heavy metals bio-mag- } \\
\text { nify but despite being a heavy metal, barium does not tend to bio-magnify. However, it forms insoluble complexes } \\
\text { with complex organic compounds (Oram n.d.). Therefore, its reduction and stability are crucial. Calcium chloride is } \\
\text { the best option here }\end{array}$ \\
\hline MAGNESIUM ION & $\begin{array}{l}\text { In the reactivity series, calcium is above magnesium thereby it has the greater tendency to lose electrons and form } \\
\text { cations- this explains its highest reduction in magnesium ions but highest increase in calcium ions concentration } \\
\text { (oxidation) }\end{array}$ \\
\hline
\end{tabular}

edge of significance. The 1st and 2 nd hypotheses were both rejected for total dissolved solids, $\mathrm{SO}^{2-}{ }_{4}, \mathrm{Cl}^{-}, \mathrm{Na}^{+}, \mathrm{Ba}^{2+}$, and $\mathrm{Fe}^{2+}$

\section{Investigation of the inter-dependence between produced water properties}

How can the experimental result be useful to the design and understanding of past and future chemical treatment data? By investigating the degree of interdependence and predictability of certain water properties, we reveal applicable knowledge which could serve as determining factors for treatment chemical selection and further insights into the complexity of coagulation chemistry. This is where the output model suitability comes in. The previous ANOVA test only covered the singular significance of each parameter. Produced water is a complex mixture and a mixture that complex requires an investigation into the relationship and interdependence between its measured parameters. A combination of correlation and regression analyses is utilized here to reveal the inter-dependence between several effluents' characteristics.
Correlation tests quantify the relationship strength between two continuous variables. It offers two main insights: the correlation coefficients and the $p$ values. Correlation coefficients range from -1 to 1 . Inverse proportionality between two variables indicates a negative correlation coefficient while direct proportionality is positive. Table 8 presents a halved correlation matrix for all analysis data. Light Red highlights indicate coefficients less than 0 (negative). Light yellow highlights cover coefficients greater than 0 but less than 1 . The 'ideal' correlation coefficients of 1 observed between $\mathrm{Na}^{+}$and $\mathrm{Cl}^{-} ; \mathrm{CaCO}_{3}$ and $\mathrm{Ca}^{2+}$ were because each pair had the same method of analysis (see Table 1) backed by long proven and widely used tests.

Assuming a significance level of $\alpha=0.05$, Table 9 displays the $P$ values for Pearson's correlation test. The light red highlights shade $P$ values greater than 0.05 ; the statistically non-significant correlations. The light green highlights indicate $P$ values less than 0.05 which are commonly deemed statistically significant. Correlations involving $\mathrm{Fe}^{2+}$ had the maximum number of statistically significant tests.

The coefficients of determination (R-squared) shown in Table 10 interpret the fitness of the regression models with 
Table 7 Contingency table for two-way ANOVA test without replication

\begin{tabular}{|c|c|c|c|c|c|c|c|}
\hline $\begin{array}{c}\text { Effluent } \\
\text { Characteristics }\end{array}$ & $\begin{array}{l}\text { Source of } \\
\text { Variation }\end{array}$ & $\begin{array}{l}\text { Sum of } \\
\text { Squares } \\
\text { sS }\end{array}$ & $\begin{array}{l}\text { Degree of } \\
\text { Freedom } \\
\text { df }\end{array}$ & $\begin{array}{l}\text { Mean } \\
\text { Square } \\
\text { MS }\end{array}$ & F-ratio & P-value & $\begin{array}{l}\text { Critical F- } \\
\quad \text { ratio }\end{array}$ \\
\hline \multirow{3}{*}{ pH } & Block/Row & 0.134 & 3 & 0.045 & 1.611 & 0.352 & 9.277 \\
\hline & Column & 1.044 & 1 & 1.044 & 37.764 & 0.009 & 10.128 \\
\hline & Error & 0.083 & 3 & 0.028 & & & \\
\hline \multirow{3}{*}{$\begin{array}{c}\text { Temperature } \\
\left({ }^{\circ} \mathrm{C}\right)\end{array}$} & Block/Row & 0.010 & 3 & 0.003 & 0.400 & 0.764 & 9.277 \\
\hline & Column & 0.005 & 1 & 0.005 & 0.600 & 0.495 & 10.128 \\
\hline & Error & 0.025 & 3 & 0.008 & & & \\
\hline \multirow{3}{*}{$\begin{array}{l}\text { Total dissolved } \\
\text { solids (mg/l) }\end{array}$} & Block/Row & 675.000 & 3 & 225.000 & 27.000 & 0.011 & 9.277 \\
\hline & Column & 450.000 & 1 & 450.000 & 54.000 & 0.005 & 10.128 \\
\hline & Error & 25.000 & 3 & 8.333 & & & \\
\hline \multirow{3}{*}{$\begin{array}{c}\text { Total } \\
\text { suspended } \\
\text { solids (mg/I) }\end{array}$} & Block/Row & 534.375 & 3 & 178.125 & 15.545 & 0.025 & 9.277 \\
\hline & Column & 3.125 & 1 & 3.125 & 0.273 & 0.638 & 10.128 \\
\hline & Error & 34.375 & 3 & 11.458 & & & \\
\hline \multirow{3}{*}{$\begin{array}{c}\text { Total } \\
\text { solids(mg/I) }\end{array}$} & Block/Row & 84.375 & 3 & 28.125 & 9.000 & 0.052 & 9.277 \\
\hline & Column & 528.125 & 1 & 528.125 & 169.000 & 0.001 & 10.128 \\
\hline & Error & 9.375 & 3 & 3.125 & & & \\
\hline \multirow{3}{*}{ Turbidity (NTU) } & Block/Row & 1.144 & 3 & 0.381 & 5.138 & 0.106 & 9.277 \\
\hline & Column & 0.382 & 1 & 0.382 & 5.138 & 0.108 & 10.128 \\
\hline & Error & 0.223 & 3 & 0.074 & & & \\
\hline \multirow{3}{*}{$\begin{array}{l}\text { Oils and Grease } \\
\qquad(\mathrm{mg} / \mathrm{l})\end{array}$} & Block/Row & 22.334 & 3 & 7.445 & 3.317 & 0.176 & 9.277 \\
\hline & Column & 159.311 & 1 & 159.311 & 70.976 & 0.004 & 10.128 \\
\hline & Error & 6.734 & 3 & 2.245 & & & \\
\hline \multirow{3}{*}{$\mathrm{SO}^{2-}{ }_{4}(\mathrm{mg} / \mathrm{l})$} & Block/Row & 8.430 & 3 & 2.810 & 15.652 & 0.025 & 9.277 \\
\hline & \begin{tabular}{|l|} 
Column \\
\end{tabular} & 2.098 & 1 & 2.098 & 11.687 & 0.042 & 10.128 \\
\hline & Error & 0.539 & 3 & 0.180 & & & \\
\hline \multirow{3}{*}{$\mathrm{Cl}^{-}(\mathrm{mg} / \mathrm{l})$} & Block/Row & 161.500 & 3 & 53.833 & 11.963 & 0.036 & 9.277 \\
\hline & Column & 2380.500 & 1 & 2380.500 & 529.000 & 0.000 & 10.128 \\
\hline & Error & 13.500 & 3 & 4.500 & & & \\
\hline \multirow{3}{*}{$\mathrm{NO}_{3}^{-}(\mathrm{mg} / \mathrm{l})$} & Block/Row & 15.024 & 3 & 5.008 & 3.121 & 0.187 & 9.277 \\
\hline & Column & 16.881 & 1 & 16.881 & 10.519 & 0.048 & 10.128 \\
\hline & Error & 4.814 & 3 & 1.605 & & & \\
\hline \multirow{3}{*}{$\mathrm{CaCO}_{3}(\mathrm{mg} / \mathrm{l})$} & Block/Row & 4297.000 & 3 & 1432.333 & 5.931 & 0.089 & 9.277 \\
\hline & Column & 4140.500 & 1 & 4140.500 & 17.145 & 0.026 & 10.128 \\
\hline & Error & 724.500 & 3 & 241.500 & & & \\
\hline \multirow{3}{*}{$\mathrm{Ca}^{2+}(\mathrm{mg} / \mathrm{l})$} & Block/Row & 687.520 & 3 & 229.173 & 5.931 & 0.089 & 9.277 \\
\hline & Column & 662.480 & 1 & 662.480 & 17.145 & 0.026 & 10.128 \\
\hline & Error & 115.920 & 3 & 38.640 & & & \\
\hline \multirow{3}{*}{$\mathrm{Na}^{+}(\mathrm{mg} / \mathrm{l})$} & Block/Row & 68.234 & 3 & 22.745 & 11.963 & 0.036 & 9.277 \\
\hline & Column & 1005.761 & 1 & 1005.761 & 529.000 & 0.000 & 10.128 \\
\hline & Error & 5.704 & 3 & 1.901 & & & \\
\hline \multirow{3}{*}{$\mathrm{Ba}^{2+}(\mathrm{mg} / \mathrm{I})$} & Block/Row & 14.070 & 3 & 4.690 & 18.411 & 0.020 & 9.277 \\
\hline & Column & 6.476 & 1 & 6.476 & 25.422 & 0.015 & 10.128 \\
\hline & Error & 0.764 & 3 & 0.255 & & & \\
\hline \multirow{3}{*}{$\mathrm{Fe}^{2+}(\mathrm{mg} / \mathrm{I})$} & Block/Row & 3.380 & 3 & 1.127 & 14.522 & 0.027 & 9.277 \\
\hline & Column & 5.346 & 1 & 5.346 & 68.914 & 0.004 & 10.128 \\
\hline & Error & 0.233 & 3 & 0.078 & & & \\
\hline \multirow{3}{*}{$\mathrm{Mg}^{2+}(\mathrm{mg} / \mathrm{I})$} & Block/Row & 0.573 & 3 & 0.191 & 46.837 & 0.005 & 9.277 \\
\hline & Column & 0.001 & 1 & 0.001 & 0.218 & 0.673 & 10.128 \\
\hline & Error & 0.012 & 3 & 0.004 & & & \\
\hline
\end{tabular}


Table 8 Correlation coefficients (Pearson) for all continuous variables

\begin{tabular}{|c|c|c|c|c|c|c|c|c|c|c|c|c|c|c|c|c|}
\hline & pH & Temperature & TDS & TSS & TS & Turbidity & $\begin{array}{l}\text { Oils and } \\
\text { Grease }\end{array}$ & $\mathrm{SO}^{2-}{ }_{4}$ & $\mathrm{Cl}^{-}$ & $\mathrm{NO}_{3}$ & $\mathrm{CaCO}_{3}$ & $\mathrm{Ca}^{2+}$ & $\mathrm{Na}^{+}$ & $\mathrm{Ba}^{2+}$ & $\mathrm{Fe}^{2+}$ & $\mathrm{Mg}^{2+}$ \\
\hline pH & 1.000 & & & & & & & & & & & & & & & \\
\hline Temperature & 0.541 & 1.000 & & & & & & & & & & & & & & \\
\hline TDS & -0.330 & 0.221 & 1.000 & & & & & & & & & & & & & \\
\hline TSS & -0.341 & -0.470 & -0.678 & 1.000 & & & & & & & & & & & & \\
\hline TS & -0.776 & -0.150 & 0.709 & 0.037 & 1.000 & & & & & & & & & & & \\
\hline Turbidity & -0.275 & 0.332 & 0.675 & -0.246 & 0.682 & 1.000 & & & & & & & & & & \\
\hline $\begin{array}{l}\text { Oils and } \\
\text { Grease }\end{array}$ & -0.771 & -0.111 & 0.717 & 0.004 & 0.978 & 0.570 & 1.000 & & & & & & & & & \\
\hline $\mathrm{SO}_{4}^{2-}$ & 0.265 & -0.155 & -0.818 & 0.532 & -0.603 & -0.468 & -0.653 & 1.000 & & & & & & & & \\
\hline $\mathrm{Cl}^{\circ}$ & -0.962 & -0.406 & 0.455 & 0.239 & 0.848 & 0.301 & 0.874 & -0.344 & 1.000 & & & & & & & \\
\hline $\mathrm{NO}_{3}$ & 0.836 & 0.668 & -0.039 & -0.387 & -0.424 & 0.239 & -0.478 & 0.026 & -0.798 & 1.000 & & & & & & \\
\hline $\mathrm{CaCO}_{3}$ & 0.437 & -0.094 & -0.605 & 0.181 & -0.649 & -0.714 & -0.576 & 0.122 & -0.530 & 0.072 & 1.000 & & & & & \\
\hline $\mathrm{Ca}^{2+}$ & 0.437 & $\begin{array}{l}-0.094 \\
\end{array}$ & -0.605 & 0.181 & -0.649 & -0.714 & -0.576 & 0.122 & -0.530 & 0.072 & 1.000 & 1.000 & & & & \\
\hline $\mathrm{Na}^{+}$ & -0.962 & -0.406 & 0.455 & 0.239 & 0.848 & 0.301 & 0.874 & -0.344 & 1.000 & -0.798 & -0.530 & -0.530 & 1.000 & & & \\
\hline $\mathrm{Ba}^{2+}$ & 0.411 & 0.055 & -0.760 & 0.362 & -0.687 & -0.380 & -0.740 & 0.966 & -0.482 & 0.221 & 0.093 & 0.093 & -0.482 & 1.000 & & \\
\hline $\mathrm{Fe}^{2+}$ & -0.583 & 0.051 & 0.769 & -0.150 & 0.902 & 0.913 & 0.816 & -0.541 & 0.626 & -0.136 & -0.781 & -0.781 & 0.626 & -0.543 & 1.000 & \\
\hline $\mathrm{Mg}^{2+}$ & 0.187 & 0.039 & 0.428 & -0.684 & -0.074 & 0.172 & -0.113 & -0.060 & -0.135 & 0.281 & -0.496 & -0.496 & -0.135 & 0.051 & 0.125 & 1.000 \\
\hline
\end{tabular}

the observed data. It ranges between 0 and 1 . The more the coefficients progress towards 1 , the better the linear fit between the correlated variables. Analysis variables with strong correlation coefficients and near- 1 coefficients of determinations were further examined in Table 11 to provide further insights regarding their inter-relationship.

In Table 11, Turbidity and $\mathrm{Fe}^{2+}$; Total Solids and Oils and Grease relationships were further examined using simple linear regression and ANOVA techniques. Each pair had direct proportionality with very impressive coefficients of determination. The dependability of total solids on $\mathrm{Fe}^{2+}$ and $\mathrm{Cl}^{-}$concentrations and the dependability of $\mathrm{pH}$ on $\mathrm{NO}_{3}^{-}$and $\mathrm{Cl}^{-}$concentrations were interpreted using multiple linear regression and ANOVA. All but $\mathrm{Cl}$ - had positive independent variable coefficients. Its negative coefficient confirms that for every unit increase in $\mathrm{Cl}^{-}$concentration, $\mathrm{pH}$ will decrease by the value of its coefficient. Relative to all variables' coefficients, their respective standard errors are small except for turbidity. The standard error tells how sufficiently precise the regression model is by calculating the average distance of the data points from the regression line (Frost 2017). Significance F represents the probability of not rejecting the regression model. It applies to the entire model while the $P$ value applies to each respective coefficient (Mathews n.d.). All significance $F$ values are below the $0.01,0.05$ and 0.1 significance levels making the models highly statistically significant. The $95 \%$ confidence intervals give estimated ranges of real coefficient values (Mathews n.d.). For instance, the coefficient for totals solids in its first model is 31.943 , there is a $95 \%$ probability that it could be as low as 25.594 and as high as 38.293. Figures 5 and 6 displays the plot of turbidity (NTU) against $\mathrm{Fe}^{2+}(\mathrm{mg} / \mathrm{l})$ and total solids (mg/l) against oils and grease (mg/l). Figures 7, 8, 9 and 10 are for the multiple linear regression outputs. They depict observed and predicted data for dependent variables against their associated independent variables. Microsoft Excel (2016) was used in creating Figs. 5, 6, 7, 8, 9 and 10.

\section{Conclusion}

The suitability of the 3 chemicals in the treatment of produced water can be summed up as follows:

\section{Dosing suitability}

The incorporation of more ionic parameters other than the conventional ones showed the reducing effects aluminium sulphate, ferrous ammonium sulphate and calcium chloride had on $\mathrm{NO}_{3}^{-}$and $\mathrm{Fe}^{2+}$ concentrations. Aluminium sulphate represents the best treatment option for physical parameters correction. For highly saline waters, ferrous aluminium sulphate is the best option. Calcium chloride is best considered when sulphate and barium levels are required to be maintained. With these groups of chemicals, the possibility of them being used as stand-alone treatment chemical isn't yet 
Table $9 P$ values (Pearson) from the correlation analysis

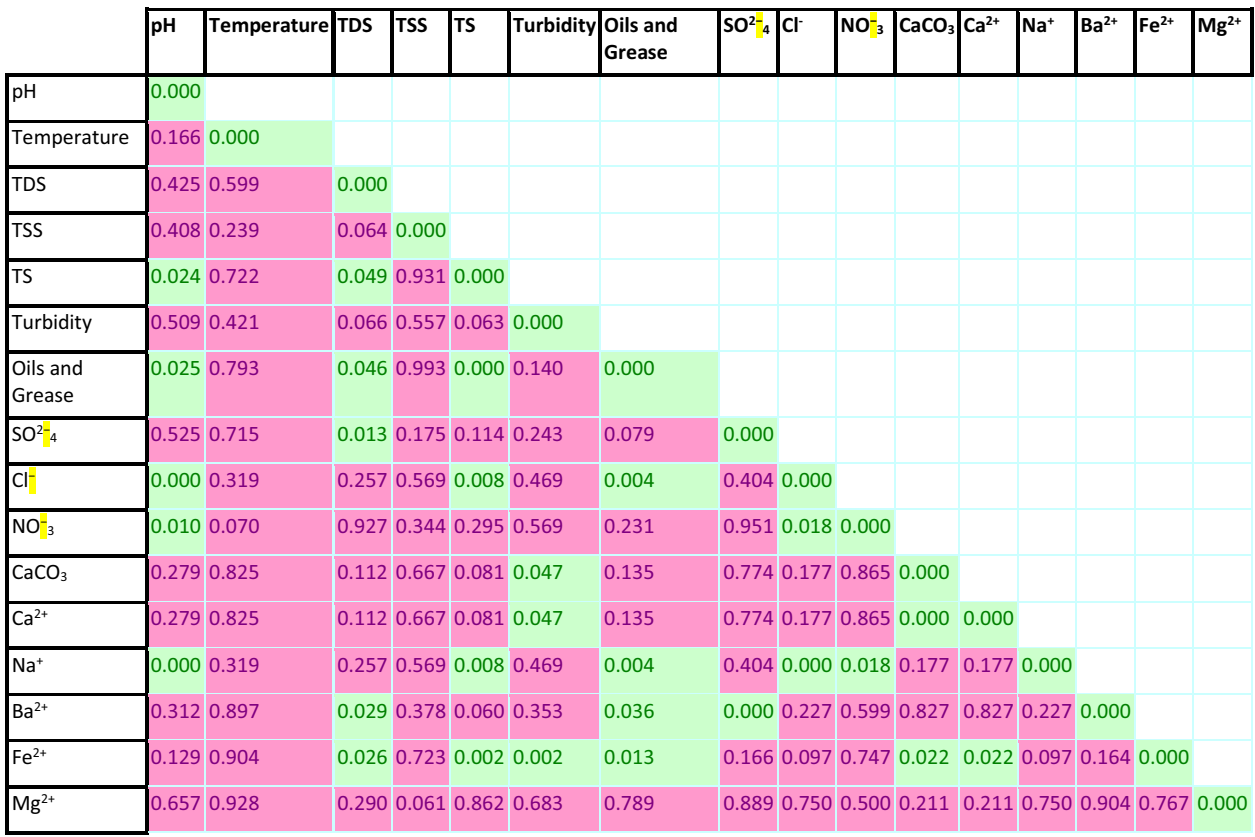

Table 10 Coefficients of determination (Pearson)

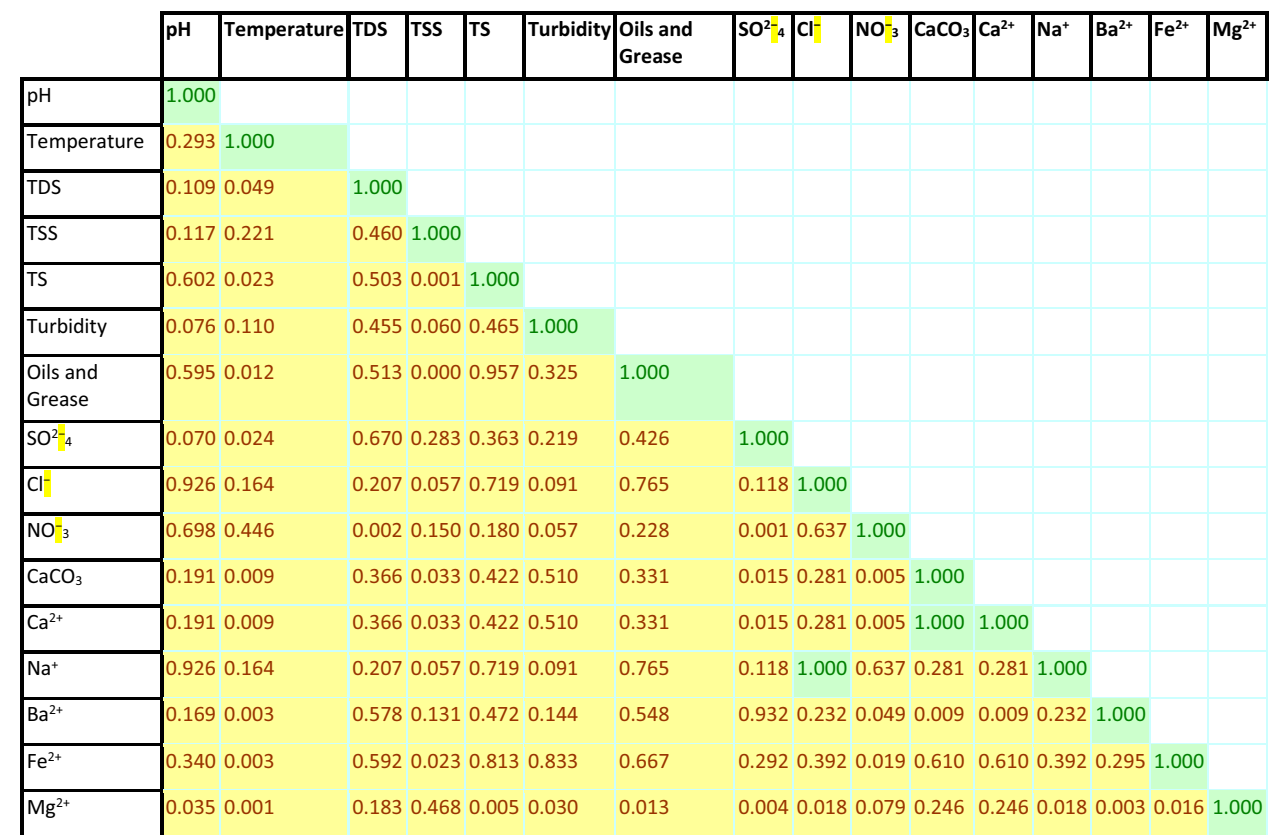

likely given the chloride, barium, and sodium ion concentration increase. The work also confirms the highly complex nature of produced water given the sometimes-non-corresponding trend between 2 different samples treated with the same chemical.

\section{Statistical suitability}

$50 \%$ of the continuous effluent characteristics (total suspended solids, total dissolved solids, total solids, $\mathrm{SO}^{2-}{ }_{4}, \mathrm{Cl}^{-}$, $\mathrm{Na}^{+}, \mathrm{Ba}^{2+}, \mathrm{Fe}^{2+}, \mathrm{Mg}^{2+}$ ) were statistically significant for the treatment chemicals hypothesis while $75 \%$ of the continuous effluent characteristics (total dissolved solids, total solids, $\mathrm{pH}$, oils and grease, $\mathrm{SO}^{2-}{ }_{4}, \mathrm{Cl}^{-}, \mathrm{NO}^{-}{ }_{3}, \mathrm{CaCO}_{3}, \mathrm{Ca}^{2+}, \mathrm{Na}^{+}$, $\mathrm{Ba}^{2+}$ and $\mathrm{Fe}^{2+}$ ) were statistically significant for the sample type hypothesis. This indicates that effluent characteristics were more influenced by the nature/composition of the produced water than the treatment chemicals used. Only $37.5 \%$ of the continuous effluent characteristics were statistically significant for both hypotheses. 

ANOVA summary output for some correlated variables
Table 11 Regression and

\begin{tabular}{|c|c|c|c|c|c|c|c|c|c|c|c|}
\hline & & Coefficients & \begin{tabular}{|l|} 
Multiple \\
R
\end{tabular} & \begin{tabular}{|l|} 
R \\
Squared
\end{tabular} & \begin{tabular}{|l|} 
Adjusted \\
R Squared
\end{tabular} & $\begin{array}{l}\text { Significance } \\
\mathrm{F}\end{array}$ & \begin{tabular}{|l|} 
Standard \\
error
\end{tabular} & \begin{tabular}{|l|}
$P$ \\
value
\end{tabular} & $\begin{array}{l}\text { Lower } \\
95 \%\end{array}$ & $\begin{array}{l}\text { Upper } \\
95 \%\end{array}$ & \begin{tabular}{|l} 
Regression \\
equation
\end{tabular} \\
\hline \multirow[t]{4}{*}{$\begin{array}{c}\text { Simple } \\
\text { linear } \\
\text { regression }\end{array}$} & \begin{tabular}{|l|} 
Intercept \\
on \\
turbidity \\
axis
\end{tabular} & 0.139 & 0.913 & 0.833 & 0.805 & 0.002 & 0.281 & 0.638 & -0.548 & 0.826 & $\begin{array}{l}\text { Predicted } \\
\text { Turbidity }= \\
0.403 \mathrm{Fe}^{2+}+ \\
0.139\end{array}$ \\
\hline & $\mathrm{Fe}^{2+}$ & 0.403 & & & & & 0.074 & 0.002 & 0.223 & 0.584 & \\
\hline & \begin{tabular}{|l} 
Intercept \\
on total \\
solids axis
\end{tabular} & 31.943 & 0.978 & 0.957 & 0.950 & 0.000 & 2.595 & 0.000 & 25.594 & 38.293 & \multirow[t]{2}{*}{$\begin{array}{l}\text { Predicted Total } \\
\text { Solids }= \\
1.777(\text { Oils and } \\
\text { Grease) + } 31.943\end{array}$} \\
\hline & $\begin{array}{l}\text { Oils and } \\
\text { Grease }\end{array}$ & 1.777 & & & & & 0.154 & 0.000 & 1.401 & 2.154 & \\
\hline \multirow[t]{6}{*}{$\begin{array}{l}\text { Multiple } \\
\text { linear } \\
\text { regression }\end{array}$} & $\begin{array}{l}\text { Intercept } \\
\text { on total } \\
\text { solids axis }\end{array}$ & 23.141 & 0.972 & 0.945 & 0.923 & 0.001 & 4.402 & 0.003 & 11.825 & 34.456 & $\begin{array}{l}\text { Predicted Total } \\
\text { Solids }=0.230 \mathrm{Fe} \\
2++5.085 \mathrm{Cl}+ \\
23.141\end{array}$ \\
\hline & $\mathrm{Fe}^{2+}$ & 0.230 & & & & & 0.066 & 0.018 & 0.059 & 0.400 & \\
\hline & $\mathrm{Cl}$ & 5.085 & & & & & 1.119 & 0.006 & 2.207 & 7.962 & \\
\hline & $\begin{array}{l}\text { Intercept } \\
\text { on pH axis }\end{array}$ & 9.136 & 0.969 & 0.938 & 0.914 & 0.001 & 0.441 & 0.000 & 8.001 & 10.270 & \multirow[t]{3}{*}{$\begin{array}{l}\text { Predicted pH = } \\
0.035 \mathrm{NO}_{3}^{-1}- \\
0.018 \mathrm{Cl}^{-}+9.136\end{array}$} \\
\hline & $\mathrm{NO}_{3}$ & 0.035 & & & & & 0.034 & 0.356 & -0.053 & 0.122 & \\
\hline & $\mathrm{Cl}^{-}$ & -0.018 & & & & & 0.004 & 0.007 & -0.029 & -0.008 & \\
\hline
\end{tabular}

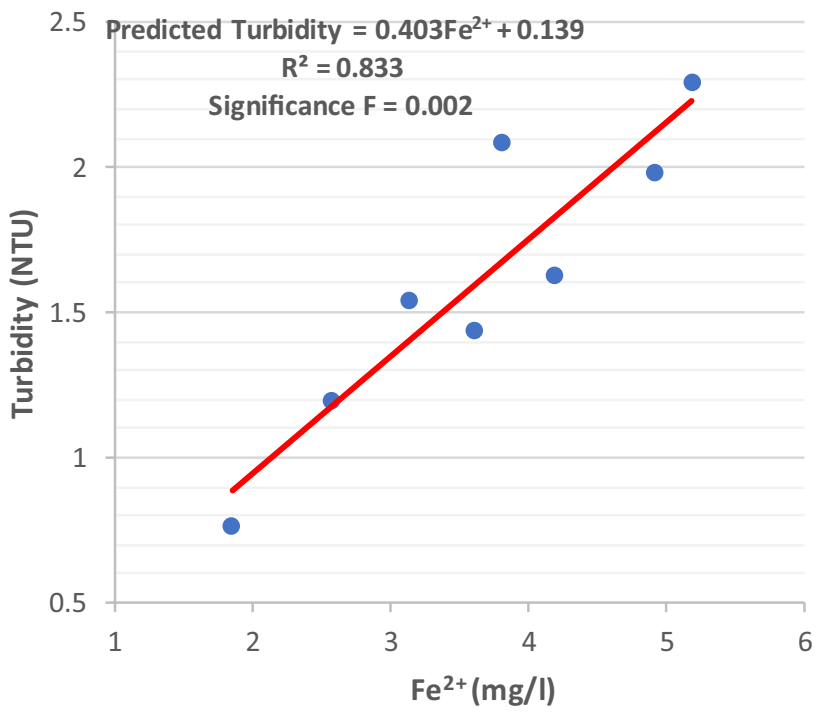

Fig. 5 Scatter plot of turbidity (NTU) against $\mathrm{Fe}^{2+}(\mathrm{mg} / \mathrm{l})$

\section{Output model suitability}

Significant strength and variable dependence were recorded and examined for 4 relationships namely turbidity and $\mathrm{Fe}^{2+}$; total solids with oils and grease; totals solids, $\mathrm{Fe}^{2+}$ and $\mathrm{Cl}^{-}$; $\mathrm{pH}, \mathrm{NO}_{3}^{-}$and $\mathrm{Cl}^{-}$. All models were statistically significant using the three most widely used significance levels.

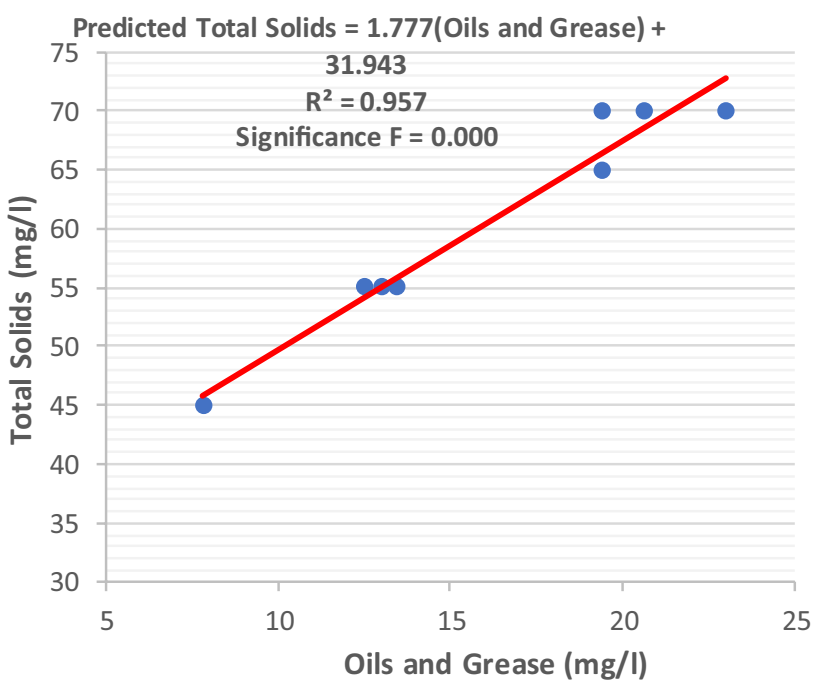

Fig. 6 Scatter plot of total solids (mg/l) against oils and grease (mg/l)

\section{Recommendation}

Increase in settling time to yield better total suspended solids and oils and grease results. The incorporation of more treatment chemicals especially those with double salt natures to create a wider spectrum of treatment options. The Department of Petroleum Resources (DPR) should set limits for newly discovered parameters with potential harm to the environment. Regulatory bodies (especially the DPR) should implement measure standards such as WQI (Water 


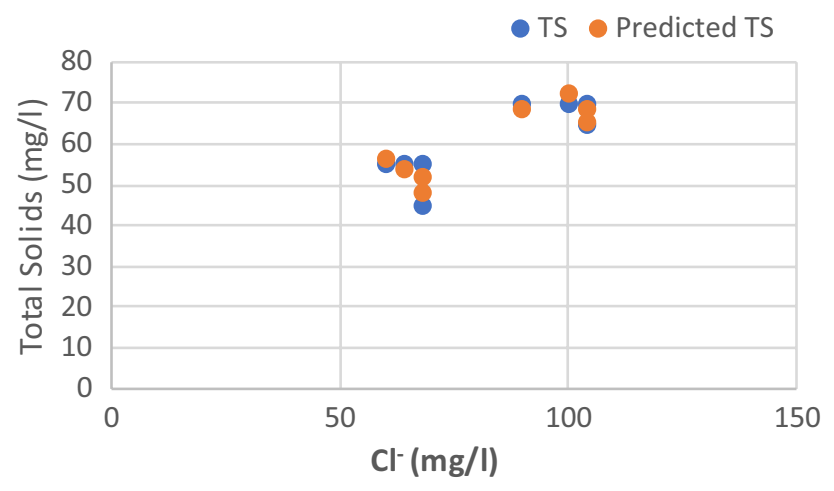

Fig. 7 Line fit plot of observed and predicted total solids $(\mathrm{mg} / \mathrm{l})$ against $\mathrm{Cl}^{-}(\mathrm{mg} / \mathrm{l})$

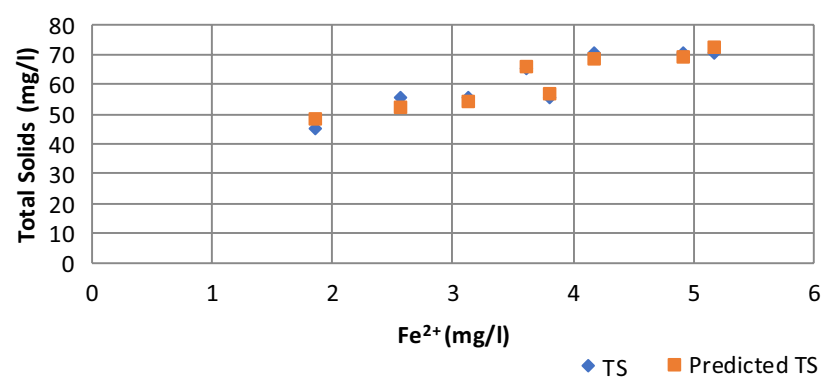

Fig. 8 Line fit plot of observed and predicted total solids (mg/l) against $\mathrm{Fe}^{2+}(\mathrm{mg} / \mathrm{l})$

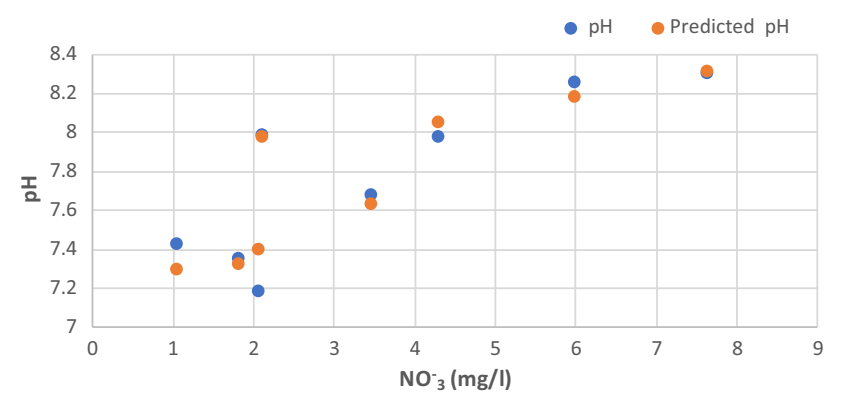

Fig. 9 line fit plot of observed and predicted $\mathrm{pH}$ values against $\mathrm{NO}_{3}^{-}$ $(\mathrm{mg} / \mathrm{l})$

Quality Index), THQ (Target Hazard Quotient) for produced water. Better liaison between the petroleum and chemistry fields in other to investigate the reaction chemistry in these options.

Acknowledgements Interning and Researching in a laboratory situated in developing countries is majorly impeded by unreliable electricity supply, insufficient funding, and forced adherence to allotted experimental schedules. With these, I would love to thank all 2018

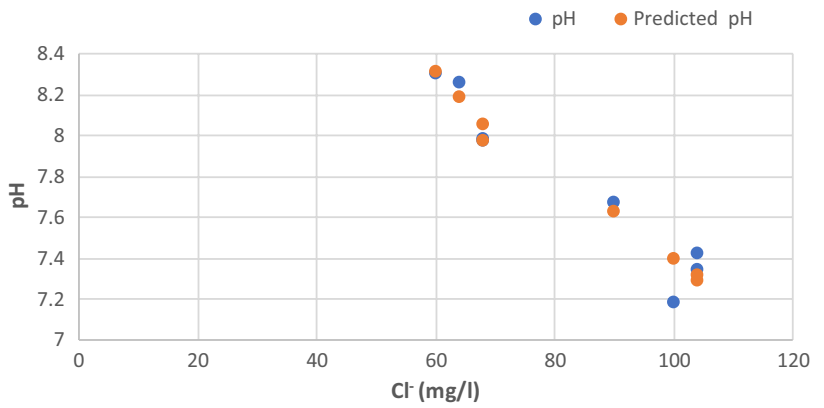

Fig. 10 Line fit plot of observed and predicted $\mathrm{pH}$ values against $\mathrm{Cl}^{-}$ $(\mathrm{mg} / \mathrm{l})$

and 2019 interns from the Petroleum Engineering Laboratory, Rivers State University, Nigeria for their commendable adaptability, positive work mindset and undeniable know-how. Also, thanks to Mrs Harmony Chimezie-Nwosu lecturer and laboratory supervisor, Petroleum Engineering Laboratory, Rivers State University for the impactful consultations; Dr Adaobi Stephenie Nwosi-Anele for granting me the research freedom when undertaking this project.

Author's contribution I am a graduate of petroleum engineering with 8 months of intensive laboratory internship at the Petroleum Engineering Laboratory, Rivers State University, Nigeria.

Funding All sections of this work including the laboratory analyses were funded and carried out by me (Clifford Okwudili Aniakor).

\section{Declaration}

Conflict of interest I, Clifford Okwudili Aniakor, the sole author of this research hereby declare that I have no conflicting interests.

Open Access This article is licensed under a Creative Commons Attribution 4.0 International License, which permits use, sharing, adaptation, distribution and reproduction in any medium or format, as long as you give appropriate credit to the original author(s) and the source, provide a link to the Creative Commons licence, and indicate if changes were made. The images or other third party material in this article are included in the article's Creative Commons licence, unless indicated otherwise in a credit line to the material. If material is not included in the article's Creative Commons licence and your intended use is not permitted by statutory regulation or exceeds the permitted use, you will need to obtain permission directly from the copyright holder. To view a copy of this licence, visit http://creativecommons.org/licenses/by/4.0/.

\section{References}

Addinsoft (2021) XLSTAT statistical and data analysis solution. New York, USA. https://www.xlstat.com.Accessed 26 April 2021

Benko KL, Drewes JE (2008) Produced water in the Western United States: geographical distribution, occurrence, and composition. Environ Eng Sci 25(2):239-246. https://doi.org/10.2172/1007397

Bennett GF (2006) Industrial waste treatment handbook. Woodward \& Curran, Inc., Butterworth-Heinemann, Burlington. ISBN: 0-75067963-8. https://doi.org/10.1016/B978-075067963-3/50009-6 
Bhandari VM, Ranade VV (2014) Industrial wastewater treatment, recycling and reuse. Butterworth-Heinemann. https://doi.org/10. 1016/B978-0-08-099968-5.00002-7

Brandt MJ, Johnson KM, Elphinston AJ, Ratnayaka DD (2017) Dams and Reservoirs. Twort's Water Supply. https://doi.org/10.1016/ b978-0-08-100025-0.00005-3

Burnett DB, Siddiqui M (2006) Recovery of fresh water resources from desalination of brine produced during oil and gas production operations. Texas A \& M Univ., College Station. Texas A \& M Engineering Experiment Station. https://doi.org/10.2172/924713

Carus Group Inc. (2019) Produced water treatment. Carus LLC. https:// www.carusllc.com/industrial/oil--gas/producedwatertreatment Accessed 2nd September 2021

Clark CE, Veil JA (2009) Produced water volumes and management practices in the US. Rep. ANL/EVS/R-09, 1

Colorado School of Mines/Advanced Water Technology Center, Kennedy/Jenks Consultants, Argonne National Laboratory (n.d.) About produced water (produced water 101). Produced Water Treatment and Beneficial Use Information Center. http://aqwat ec.mines.edu/produced_water/intro/pw/index.htm

Dubois S (n.d.) The importance of hypothesis testing. Sciencing. https://sciencing.com/the-importance-of-hypothesis-testing-12750 921.html Accessed 2nd Sept 2021

Fakhru'l-Razi A, Pendashteh A, Abdullah LC, Biak DRA, Madaeni SS, Abidin ZZ (2009) Review of technologies for oil and gas produced water treatment. J Hazard Mater 170(2-3):530-551. https://doi. org/10.1016/j.jhazmat.2009.05.044

Fondriest Environmental Inc (2014) Turbidity, total suspended solids and water clarity. Fundamentals of Environmental Measurements. https://www.fondriest.com/environmental-measurements/param eters/water-quality/turbidity-total-suspended-solids-water-clarity/ Accessed 13th May 2021

Frost J (2017) Standard error of the regression vs r-squared. Statistics By Jim. https://statisticsbyjim.com/regression/standard-errorregression-vs-r-squared/ Accessed 13th May 2021

Hosny H, Ramzi M (2017) Chemical treatment of produced water to reduce formation damage. LAP LAMBERT Academic Publishing. ISBN: 978-3-330-07180-3

Igunnu ET, Chen GZ (2014) Produced water treatment technologies. Int J Low Carbon Technol 9(3):157-177. https://doi.org/10.1093/ ijlct/cts049

Igwe CO, Saadi AA, Ngene SE (2013) Optimal options for treatment of produced water in offshore petroleum platforms. J Pollut Eff Cont. https://doi.org/10.4172/2375-4397.1000102

Jones B (2020) Inorganic and organic coagulant: making an informed decision. Veolia Water Technology. https://www.blog.veoliawate rtechnologies.co.uk/inorganic-vs-organic. Accessed 2nd Sept 2021

Li G, An T, Chen J, Sheng G, Fu J, Chen F, Zhang S, Zhao H (2006) Photoelectrocatalytic decontamination of oilfield produced wastewater containing refractory organic pollutants in the presence of high concentration of chloride ions. J Hazard Mater. https://doi. org/10.1016/j.jhazmat.2006.05.083

Liangxiong L, Ryan A, Nenoff TM, Dong J, Lee R (2004) Purification of coal-bed methane produced water by zeolite membranes. In: SPE annual technical conference and exhibition. OnePetro

Markey CM, Michaelson CL, Sonnenschein C, Soto AM (2001) Alkylphenols and bisphenol A as environmental estrogen. In: Endocrine disruptors-part 1. Springer, Berlin, pp 129-153. https://doi.org/ 10.1007/10690734_7

Mathews S (n.d.) Interpreting regression output (without all the statistic theory). Graduate tutor. https://www.graduatetutor.com/stati stics-tutor/interpreting-regression-output/\#: :text=Statistically\% 20speaking $\% 2 \mathrm{C} \% 20$ the $\% 20$ significance $\% 20 \mathrm{~F}$,regression $\% 20 \mathrm{mod}$ el $\% 20$ cannot $\% 20$ be $\% 20$ rejected.\&text=it $\% 20$ is $\% 20 \mathrm{a} \% 20$ ratio $\%$ 20computed,to\%20a\%20very\%20large\%20number Accessed 13th May 2021

Nickerson RS (2000) Null hypothesis significance testing: a review of an old and continuing controversy. Psychol Methods 5(2):241. https://doi.org/10.1037/1082-989X.5.2.241

Nwosi-Anele AS, Iledare OO (2016) Produced water treatment methods and regulations: lessons from the Gulf of Mexico and North Sea for Nigeria. Am J Eng Res (AJER) 5(12):46-57

Oram B (n.d.) Barium and other salts in drinking water (saline water/ brine water). B.F. Environmental Consultants Inc., Water Testing Kits-Do it Yourself at Home! Commercial Filtration Supply. https://water-research.net/index.php/barium Accessed 12th May 2021

Pimentel PM, Anjos MJ, Melo DMDA, Melo MAF, Gonçalves LM Jr, Silva CN Jr, Lopes RT (2008) Multi-elemental analysis of produced water by synchrotron radiation total reflection X-ray fluorescence. Talanta 74(5):1231-1235. https://doi.org/10.2118/ 89892-ms

Rodriguez AZ, Wang H, Hu L, Zhang Y, Xu P (2020) Treatment of produced water in the permian basin for hydraulic fracturing: comparison of different coagulation processes and innovative filter media. Water 12(3):770. https://doi.org/10.3390/w12030770

Udeagbara SG, Isehunwa SO, Okereke NU, Oguamah IU (2021) Treatment of produced water from Niger Delta oil fields using simultaneous mixture of local materials. J Pet Explor Prod 11(1):289 302. https://doi.org/10.1007/s13202-020-01017-w

United Nations Human Rights Office of the High Commissioner UN OHCR (2021) UN expert: water crisis is worsening, urgent response needed. Office of the High Commissioner (OHCR). https://www.ohchr.org/EN/NewsEvents/Pages/DisplayNews.aspx? NewsID=26835\&LangID=E Accessed 2nd Sept 2021

Zakwan M, Sahak M, Aris MS, Ariff IF, Saadon S, Muhammad MF, Radi NM, Daud NM (2018) Chemical treatment of toxic produced water from offshore chemical enhanced oil recovery applications for overboard discharge. In: Offshore technology conference Asia. OnePetro. https://doi.org/10.4043/28456-MS 